of a Marine Biological Station at the entrance to Port Jackson, both being the property of the University. This biological station is at present the only one permanently equipped and in continuous use on the Australian coast.

\section{Seasonal Plankton Rhythm}

At the recent meeting of the Australian and New Zealand Association for the Advancement of Science, it was stated by Prof. Dakin that plankton studies in New South Wales waters had shown a distinct diatom maximum in the spring, followed by a smaller maximum in the autumn. These conditions presented an interesting and close parallel with those so well known in the temperate waters of Europe. In further agreement a scarcity of plankton is recorded during the winter months and the planktonic CrustaceaCopepoda and Cladocera - rise to maxima in the early summer following the diatom and dinoflagellate maxima. The variations in the abundance of plankton during the year do not seem to be anything like so great as in the Irish Sea or English Channel, and it would almost appear as if the phosphate and nitrate concentrations in the sea water were also more uniform. The study of the relation between the seasonal rhythm of the plankton and changes in the physico-chemical environment is to be continued, whilst particular attention will be paid to the occurrence of fish eggs and larvæ.

\section{Fisheries of the Philippines}

Three fully illustrated accounts of various Philippine fisheries are published in the July number of the Philippine Journal of Science, No. 3, vol. 48, 1932 : "The Japanese Beam Trawl used in Philippine Waters", by Augustin F. Urnali ; "The Fisheries of Lake Sampaloc, San Pablo Laguna Province, Luzon", by Florencio Talavera; and "Fishing Appliances of Panay, Negros and Cebu", by Florencio Talavera and Heraclio R. Montalban. Fishes of many kinds, shrimps and other Crustacea, molluses and holothurians are all important commercially in the Philippines. In some parts the fishing is deteriorating from over-fishing, lack of attention, or from physical causes. New methods and restrictions are recommended by the different writers. The Japanese beam trawl is at present used only by Japanese, in their own boats, manned by their own men. It is apparently no more destructive than the other methods of fishing, and its use is advised for the native fishermen. Lake Sam. palac, the largest of the nine crater lakes in the San Pablo Valley, was an important fishing centre before its height was lessened by approximately 10 metres. Now, partly from this alteration and partly from other causes which are investigated fully by Dr. Talavera, of the Division of Fisheries, Bureau of Science, Manila, the fishes are certainly decreasing, and legislative measures together with restocking are suggested. The shrimps in this lake appear to be inexhaustible. The multiplicity of terms used in the local fisheries and the names for the various appliances are astonishing, but these are all carefully explained and illustrated in the third paper.

\section{Oceanography in Spain}

IN June 1933 the first Iberian-American Oceanographical Conference will be held in Madrid. The Council, under the presidency of Prof. D. Odon de Buen of Madrid, was instituted in 1929 in order to facilitate co-operation between the Iberian Peninsula and parts of America, the countries involved being Spain, Argentina, Costa Rica, Ecuador, Salvador, Guatemala, Mexico, Panama, Peru, Dominican Republic, and Uruguay. The publications of the Council consist of a review (Revista del Consejo Oceanografico Ibero-Americano), which has been in existence for three years and contains many interesting short papers, and the memoirs (Memorias del Consejo Oceanografico Ibero-Americano), eleven numbers of which have been published, each containing one long paper. No. 9, by Prof. Rafael de Buen, deals with all the activities connected with the Spanish Institute of Oceanography, which was founded in 1914 to unite in one centre the coastal marine laboratories already in existence, situated in Palma de Mallorca, Malaga, and Santander. All these are now connected with the main oceanographical laboratories in Madrid, where all investigations are centralised, the director being Prof. Odon de Buen. Various expeditions have been undertaken, mainly in the Mediterranean, and in 1924 Spain joined the International Council for the Exploration of the Sea, among other things working out certain hydrographical problems round Cape Finisterre and studying the biology of the sardine and other fishes, including the hake, tunny, and bonito.

\section{Tasmanian Rock Carvings}

A Discussion of the origin of certain alleged rockengravings at Mersey Bluff, Devonport, Tasmania, appears in the Papers and Proceedings of the Royal Society of Tasmania for 1931. In its general bearing the paper is of considerable interest to archæologists and students of primitive art. Mr. A. L. Meston, who argues for the authenticity of the carvings, has examined and describes a number of them. $\mathrm{He}$ claims that he has identified representations of fish, coiled snakes, a bird's head, Haliotis shells, cup-andrings, and concentric circles. The carvings are on horizontal surfaces of a hard diabase, and are not scratched but are incised, as if by a hard implement, such as a quartzite tool, impelled by a hammer. The existence of Tasmanian aboriginal carvings and draw. ings has been doubted, notably by the late H. Ling Roth; but Mr. Meston states that these examples have been accepted by those acquainted with primitive rock-carvings elsewhere. The case against the authenticity of these carvings is taken up by Mr. E. O. G. Scott, of the Queen Victoria Museum, Launceston, who has made an extensive and detailed report on the subject to the Museum Committee. A brief outline of his arguments appears in the Proceedings, pending decision as to publication in full. His conclusion is that the 75 rock-markings claimed by Mr. Meston to be carvings are not of aboriginal origin, but are items in an extensive series of natural erosions which have in general occurred along lines

No. 3292, Vol. 130] 